TAMARA BANJEGLAV

\title{
Exhibiting Memories of a Besieged City. The (Uncertain) Role of Museums in Constructing Public Memory of the 1992-1995 Siege of Sarajevo
}

\begin{abstract}
The author examines museums in Sarajevo, the capital of Bosnia and Herzegovina, and their exhibitions dealing with the city's most traumatic event in recent history-the 1992-1995 siege. She analyses how the interpretations and re-interpretations of history in these museums have been affected by social, political, cultural, and institutional contexts, and how various 'memory entrepreneurs' have played a role in building the public memory of the city's siege. The analysis focuses on, but is not limited to, three museums: the History Museum of Bosnia and Herzegovina, the Tunnel Museum, and the War Childhood Museum. This discussion is supplemented by an analysis of other museums in Sarajevo that also demonstrate how the political deadlock in the country has affected the cultural sector. The author argues that the various museums to have opened in Sarajevo in recent years indeed have the potential to become crucial public spaces where authoritative notions of history, memory, and identity can be critically examined, negotiated, and contested.
\end{abstract}

Tamara Banjeglav, currently an independent scholar, received her PhD degree in Diversity Management and Governance from the University of Graz, Austria, and has worked as a post-doctoral researcher at the University of Rijeka, Croatia.

\section{Introduction}

At a time when the war in Bosnia and Herzegovina (hereafter: $\mathrm{BiH}$ ) was taking place, in the late twentieth century, a significant shift occurred in how societies and nations around the world memorialized violent pasts. As Amy Sodaro argues, 'the impulse to preserve and remember so that atrocity will "never again" happen has driven memorialization from the second half of the twentieth century through today'.1 Today, museums and memorials are public spaces with the potential to institutionalize the 'never again' pledge. Museums are, on the one hand, political spaces related to questions of

\footnotetext{
1 Amy Sodaro, Exhibiting Atrocities. Memorial Museums and the Politics of Past Violence, New Brunswick et al. 2018, 4.
} 
representation and power, while on the other, they are also critical spaces that open the possibility to re-interpret the past and negotiate (political) identities. ${ }^{2}$

In this article, I analyse how the interpretation and re-interpretation of recent history in museums in the capital of $\mathrm{BiH}$, Sarajevo, has been affected by social, political, cultural, and institutional contexts. I aim to inform debates focusing on the way museums interact with processes of political and societal change, thereby tackling the question of how museums shape public memories of the past in situations in which they, as cultural and educational institutions, are neglected by authorities that do not perceive them as state institutions. What happens when museums lose their national importance and wider social impact and become bottom-up rather than top-down initiatives? How to approach these institutions when the state does not view them or show interest in them as part of national cultural heritage? What can we learn by analysing and comparing various examples of museums that deal with recent war history?

In the following, I answer these questions by examining museums in Sarajevo that host exhibitions dealing with the 1992-1995 siege of the city. Sarajevo has been chosen for this case study due to the proliferation, in recent years, of museums and museum initiatives around one of the most traumatic events in the city's recent history. These museums have been initiated by various 'memory entrepreneurs', a term coined by Elizabeth Jelin to refer to various social groups that 'participate in the memory negotiations, following strategies that may be convergent or contrary to the policies of the state.'. According to Jelin, the voices of such 'entrepreneurs' are diverse: some are louder than others, depending on how close or distant they are from instances of power. ${ }^{4}$ In this article, the term 'memory entrepreneur' is expanded to include all memory activists with financial ('entrepreneurial') or other investments in the museums and/or museum initiatives analysed. I thus discuss various memory activists in Sarajevo and their roles in constructing the public memory of the city's siege. Public memory is here understood in line with John Bodnar's definition as 'a body of beliefs and ideas about the past that help a public or society understand both its past, present, and by implication, its future. It is fashioned ideally in a public sphere in which various parts of the social structure exchange views'. ${ }^{5}$

\footnotetext{
${ }^{2}$ Celeste Ianniciello / Michaela Quadraro, Museum Practices and Migrating Modernity. A Perspective from the South, Stedelijk Studies Journal 1 (2014), https://stedelijkstudies.com/ journal/museum-practices-and-migrating-modernity-a-perspective-from-the-south/. All internet references were accessed on 15 February 2019.

${ }^{3}$ Elizabeth Jelin, State Repression and the Labors of Memory, Minneapolis/MN 2003, 35.

${ }^{4}$ Jelin, State Repression and the Labors of Memory, 36.

${ }^{5}$ John Bodnar, Remaking America. Public Memory, Commemoration and Patriotism in the Twentieth Century, in: Jeffrey K. Olick / Vered Vinitzky-Seroussi / Daniel Levy, eds, Collective Memory Reader, Oxford 2011, 265-268, 266.
} 
In my analysis of the examined museums, I adopt an ethnographic approach that takes account of the social and historical contexts within which the museums are embedded. This approach, however, also gives consideration to elements such as the museum building, its collections, individual staff, and institutional status. ${ }^{6}$ All these aspects together help us to understand the meanings of a museum. Empirically, the article is based on primary research, including the examination of museum exhibitions, interviews with museum employees, the observation of other activities within the museums, the analysis of the museums' print and online publications, as well as an analysis of local media. The analysis focuses on, but is not limited to, three museums: the History Museum of Bosnia and Herzegovina, the Tunnel Museum and the War Childhood Museum. The discussion is supplemented by an analysis of other museums in the city that also demonstrate how the political deadlock in the country has affected the cultural sector.

The Socialist Federal Republic of Yugoslavia (SFRY) saw a boom in the establishment of new national museums after the Second World War. The aim was to establish an interpretation of the contemporary past in line with the communist government's master narrative of the Second World War. Victory in the war was to be remembered as the main social experience that gave legitimacy and meaning to the new Yugoslav state. The Communist Party sought to determine what was to be publicly remembered and what was to be forgotten, while the official interpretation of the Second World War prevailed in all aspects of public life: education, state holidays, museums, names of public spaces, and popular culture. The national museums played an important part in the construction of the official narrative and served the purpose of bringing people together in order to strengthen the unity of the Yugoslav peoples and to promote the idea of a socialist society.

With the break-up of Yugoslavia in the early 1990s, all these national institutions saw their ideological and political dimensions change, their identity markers, as well as their names. ${ }^{7}$ Another major change, as this article argues on the basis of the example of Bosnia and Herzegovina, concerned the sources of support for museums and other memorialization initiatives. The single state structure that had underpinned museums and their narratives collapsed.

In Bosnia and Herzegovina, the 1992-1995 war resulted not only in great human and material losses, but also in the destruction of BiH's culture, specifically its multiculturalism, which before the war had been characteristic of

\footnotetext{
${ }^{6}$ Rhiannon Mason, Cultural Theory and Museum Studies, in: Sharon Macdonald, ed, A Companion to Museum Studies, Hoboken/NJ 2006, 17-32, 26.

${ }^{7}$ For a wider discussion cf. Peter Aronsson / Gabriella Elgeniu, eds, Building National Museums in Europe 1750-2010. Mobilization and Legitimacy, Continuity and Change, London, New York/NY 2011.
} 
Bosnian society. ${ }^{8}$ The destruction of culture continued even after the war and the signing of the Dayton Agreement in December 1995 through the implementation of a complex government system and mutually exclusive, ethnopolitical institutional frameworks. ${ }^{9}$ Political scientist Asim Mujkić has defined ethnopolitics as

'such a political context where a person's citizenship is predetermined by her or his kinship, or her or his belonging to this or that group of mutual blood origin. The subversive mechanism of Ethnopolitics consists in practice of presenting ethnos as demos, where ethnos acts like demos thus, paraphrasing Balibar, becoming an imaginary community of belongingness and connection of the kinship as collective subject of the representation, decision-making and law. ${ }^{10}$

The Dayton Agreement confirmed the wartime fragmentation of $\mathrm{BiH}$ along ethnonational lines and divided the country into two ethnically defined entities, the Serb-dominated Republika Srpska and the Bosniak-Croat Federation of Bosnia and Herzegovina. The Federation of $\mathrm{BiH}$ was further divided into ten federal units or cantons, each with its own administration. Due to this division of the country, the three ethnopolities (Serb, Croat, and Bosniak) have continued to compete, emphasizing the need to protect the identity and interests of their respective ethnonational group. ${ }^{11}$ Also, the country's two entities have separate cultural and educational policies that are implemented with no coordination between them. This discord between the opposing ethnopolitical elites is visible, as Melina Sadiković has noted, in the 'existing models of segregation in education, and a crisis in culture, which is manifested through a failure to provide adequate support to cultural institutions that preserve the shared cultural heritage of the country'. ${ }^{12}$ Moreover, the Dayton Agreement failed to establish a state-level ministry of culture, even though it recognized as national cultural institutions seven museums, galleries, and libraries

\footnotetext{
${ }^{8}$ For a detailed analysis of the destruction of cultural heritage during the war in $\mathrm{BiH}$ cf. Helen Walasek et al., Bosnia and the Destruction of Cultural Heritage, London, New York/ NY 2015.

9 The General Framework Agreement for Peace in Bosnia and Herzegovina, also known as the Dayton Agreement or Dayton Accords, is the peace agreement reached at Dayton, Ohio, United States, in November 1995 and formally signed in Paris on 14 December 1995. The agreement put an end to the 3.5-year-long war in Bosnia and Herzegovina.

${ }_{10}$ Asim Mujkić, We, the Citizens of Ethnopolis, Sarajevo 2008, 20.

${ }^{11}$ Nicolas Moll, Fragmented Memories in a Fragmented Country. Memory Competition and Political Identity-Building in Today's Bosnia and Herzegovina, Nationalities Papers. The Journal of Nationalism and Ethnicity 41, no. 6 (2013), 910-935, DOI: 10.1080/00905992.2013.768220.

${ }_{12}$ Melina Sadiković, Bosnian-Herzegovinian Culture Between Erasure and Ethnopolitics. Reflections on the Crisis of National Cultural Institutions, Museological Review 20 (2016), 84-93.
} 
that were established by the Socialist Republic of BiH. ${ }^{13}$ As Susan Pearce and Jasmin Mujanović argue, it also 'required that governmental entities take public stands on the oversight, leadership, and care of these institutions. To date, none of the entities have stepped up to the plate. ${ }^{14}$ How such failure to take care of these cultural institutions has affected the museum sector is discussed in more detail in the following.

\section{The History Museum of BiH. Whose History in Whose Museum?}

The History Museum of Bosnia and Herzegovina was founded in Sarajevo in 1945 as the Museum of National Liberation. In November 1945, the presidency of the National Assembly of Bosnia and Herzegovina decreed the 'Law on the Foundation of the Museum of National Liberation' as a state institution under the direct control of the Ministry of Education. ${ }^{15}$ The task of the Museum was to

'collect, preserve and display all documents related to the course and development of the national liberation fight and its achievements, to collect, study and reveal to the public all source materials which relate to the history of the national liberation war, and to preserve and cherish the remembrance of the national heroes and victims of fascism, of the heroism and devotion of our peoples in the liberation war'.16

This clear focus on the events and consequences of the Second World War was reflected in the original name of the museum, the 'Museum of National Liberation'. In 1950, the museum was renamed 'Museum of the National Revolution of Bosnia and Herzegovina', and in 1967, 'Museum of the Revolution of Bosnia and Herzegovina'. The implicit aim of the museum was to legitimize communist rule through an emphasis on the importance of the partisan movement for the liberation of the peoples of Bosnia and Herzegovina, as well as of Yugoslavia, and through remembrance of the suffering of its peoples during the war, while underlining the dangers of divisive ideologies such as fascism and nationalism. ${ }^{17}$ Its name today, the History Museum of Bosnia and Herzegovina, was adopted during the recent war, in $1993 .{ }^{18}$ These name changes

${ }^{13}$ Susan C. Pearce/Jasmin Mujanović, Local Challenges, Global Implications. Bosnia Herzegovina's Cultural Institutions in Crisis, Emerging Democracies Institute, no date, https://thebalkanforum.org/file/repository/RE71.pdf.

${ }_{14}$ Pearce / Mujanović, Local Challenges, Global Implications.

${ }^{15}$ Muniba Kaljanac, Sixty Five Years of the History Museum of Bosnia and Herzegovina, Sarajevo 2010, 7.

${ }^{16}$ Kaljanac, Sixty Five Years of the History Museum of Bosnia and Herzegovina, 7.

${ }^{17}$ Kaljanac, Sixty Five Years of the History Museum of Bosnia and Herzegovina, 15.

${ }^{18} \mathrm{Cf}$. the 'About' page on the website of the History Museum of Bosnia and Herzegovina, http://muzej.ba/collections-research/about-the-museum/. 


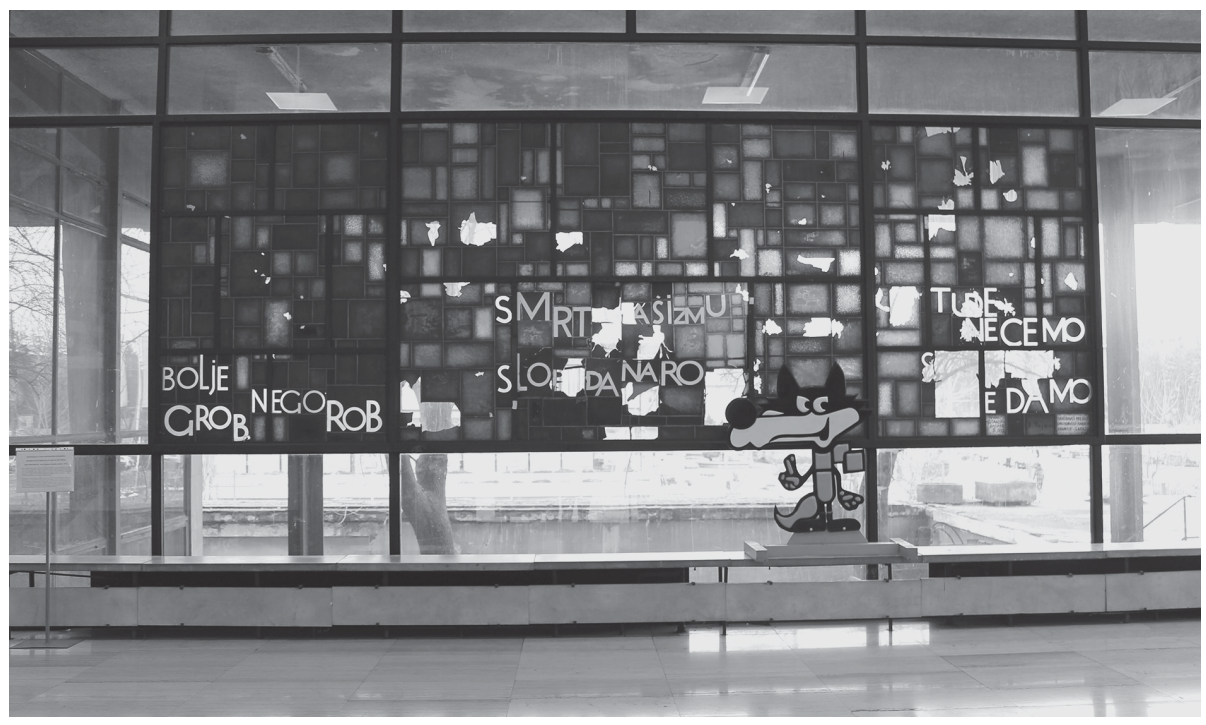

Image 1: History Museum of Bosnia and Herzegovina, stained glass panel at the museum's entrance. Source: Vjeran Pavlaković.

already indicate how the thematic focus and purpose of the museum changed throughout the years. This process included a broadening of the scope of the museum's work and, in 1993, the redefinition of the History Museum of BiH as a museum dealing with all periods of Bosnian and Herzegovinian history. In a report to the Council of Europe in 1996 on museums in Bosnia and Herzegovina during the war, Helen Walasek and Marian Wenzel noted that

'the former Museum of the Revolution in Sarajevo is trying to redefine itself as the Historical Museum of Bosnia-Herzegovina. Staff feel there will be a need after the war to research the history of the country from the arrival of the Slavs to the present and that no other museum fulfils this purpose. ${ }^{\prime 19}$

Perhaps the clearest evidence of the changes and difficulties to confront the History Museum is the stained glass panel still standing at the museum's entrance. It reads Smrt fašizmu, sloboda narodu (Death to fascism, freedom to the people). Some of the letters are smashed, and some are missing, testifying to the fact that the museum was situated directly on the front line during the war. However, the museum collections were protected and preserved owing to the efforts of the museum staff. Today, the museum building still bears the

${ }^{19}$ Committee on Culture and Education, Report on Museums in Bosnia-Herzegovina during the Present War, Doc. 7464, Ninth Information Report, 19 January 1996, https://assembly. coe.int/nw/xml/XRef/X2H-Xref-ViewHTML.asp?FileID=7398. 
scars of the war and is in a dire condition. For example, there is no heating in the building in winter. In order precisely to contextualize the museum and its permanent exhibition, it is important to reflect on the financial situation and condition of the museum which today struggles with numerous difficulties.

The History Museum of $\mathrm{BiH}$ is one of the seven Sarajevan national cultural institutions recognized as such by the Dayton Accords. The other six are the National Museum, the National and University Library, the Art Gallery, the National Film Archive, the Museum of Literature and Theatre Arts, and the Library for the Blind and Visually Impaired. Due to the complex political system of the country, all find themselves in a perpetual funding crisis. As Melina Sadiković points out, 'the institutions are vastly different in terms of their function, but all are located in Sarajevo and concerned with the protection and presentation of Bosnian-Herzegovinian cultural heritage' ${ }^{20}$

The division of the country into two entities, as already discussed above, has left the former state-level institutions caught on a boundary line, so that neither the state nor entity governments want to take responsibility for them. ${ }^{21}$ The biggest problem for the History Museum is the fact that there is no Ministry of Culture at state level, only at entity level, yet the museum is not an entity-level institution. As the museum's director explains, 'from 1995 until today, the museum has had no legal status. It is one of the seven institutions that have been left floating in the air. None of the ministries or levels of government have taken over responsibility either for appointing the museum management or for its finances.'22 Thus, Bosnia and Herzegovina's only historical museum, the purpose and task of which is to narrate the country's history, is not financed by any level of government, has no legal status and no governing bodies that would take over responsibility for its operation. The museum is left with the difficult task of presenting and discussing the history of a country that is not only divided along ethnonational lines, but is also divided in terms of whether its citizens believe in the existence of such a thing as a shared history of Bosnia and Herzegovina. As the museum's director explains, 'we are abandoned because we try to open up dialogue and show the shared history of a divided country' ${ }^{23}$ The authorities regard the museum as redundant because of its inherited idea of a shared Bosnian-Herzegovinian culture and history. This attitude is reflected in the fact that the Sarajevo city

\footnotetext{
${ }^{20}$ Sadiković, Bosnian-Herzegovinian Culture between Erasure and Ethnopolitics, 86.

${ }^{21}$ For a detailed discussion of the particularly difficult year of 2012 for the seven cultural institutions, cf. Sadiković, Bosnian-Herzegovinian Culture between Erasure and Ethnopolitics.

${ }^{22}$ Interview with Elma Hašimbegović, director of the History Museum of BiH, Sarajevo, 19 November 2015.

${ }^{23}$ Elma Hašimbegović, director of the History Museum of $\mathrm{BiH}$, during a museum workshop on 27 June 2017.
} 


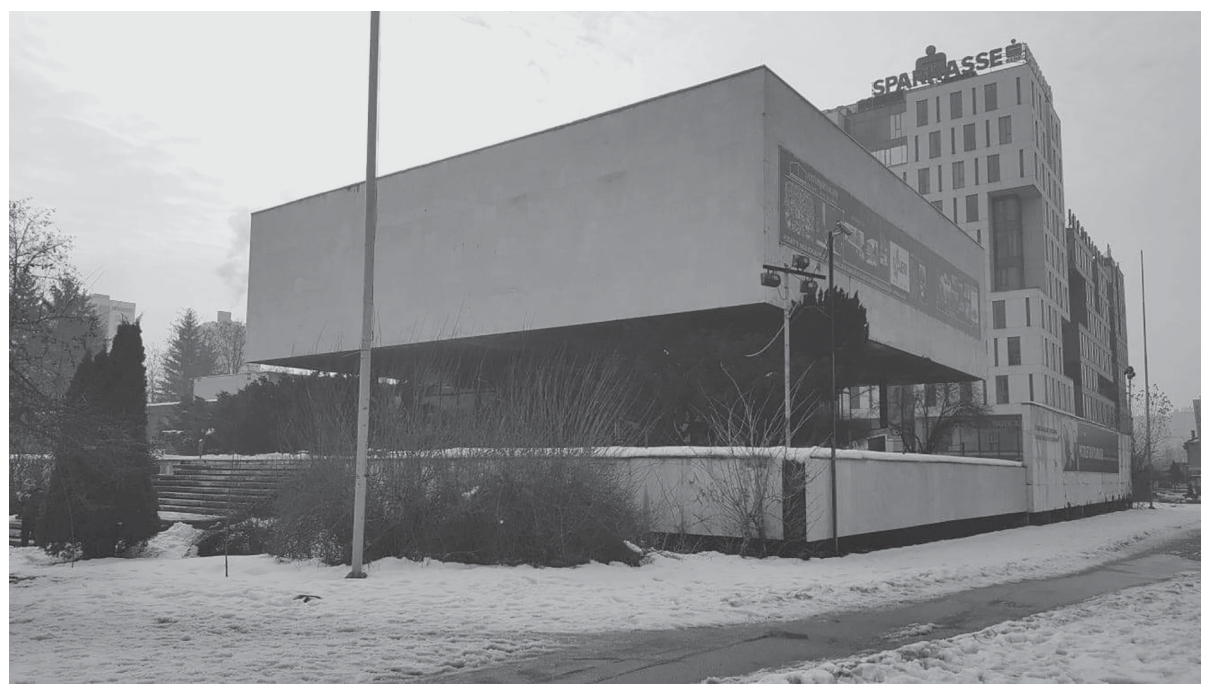

Image 2: History Museum of Bosnia and Herzegovina. Source: Vjeran Pavlaković.

authorities in 2014 stopped providing symbolical financial support for the 'Besieged Sarajevo' exhibition, which the museum had received for several years. ${ }^{24}$ Such a lack of interest on the part of official institutions in the city's most comprehensive exhibition about the siege reflects a general lack of interest by both local (entity) and state-level authorities in the History Museum itself.

Yet despite these problems and lack of funding, the museum has hosted several important exhibitions, including its now permanent exhibition, 'Besieged Sarajevo'. The exhibition has been shown at the museum in one form or another since 2003, interrupted only for a period of fifteen months between 2004 and 2005 when it was on display in Sweden while the History Museum was closed due to insufficient funds. ${ }^{25}$

The 'Besieged Sarajevo' exhibition focuses on the 1992-1995 siege of the city and shows the daily life of civilians and their experience of living under the siege, while avoiding to mention any political and military context of the war. It tells a story of improvisation and resourcefulness during the struggle

\footnotetext{
${ }^{24}$ Đorđe Krajišnik, Moramo opstati jer radimo dobre i važne stvari, Dani, 30 January 2015, 54.

${ }^{25}$ Emily Gunzburger Makaš, Museums and the History and Identity of Sarajevo, paper presented at the European Association for Urban History 11th International Conference on Urban History, 'Cities and Societies in Comparative Perspective', Prague, 29 August - 1 September 2012.
} 


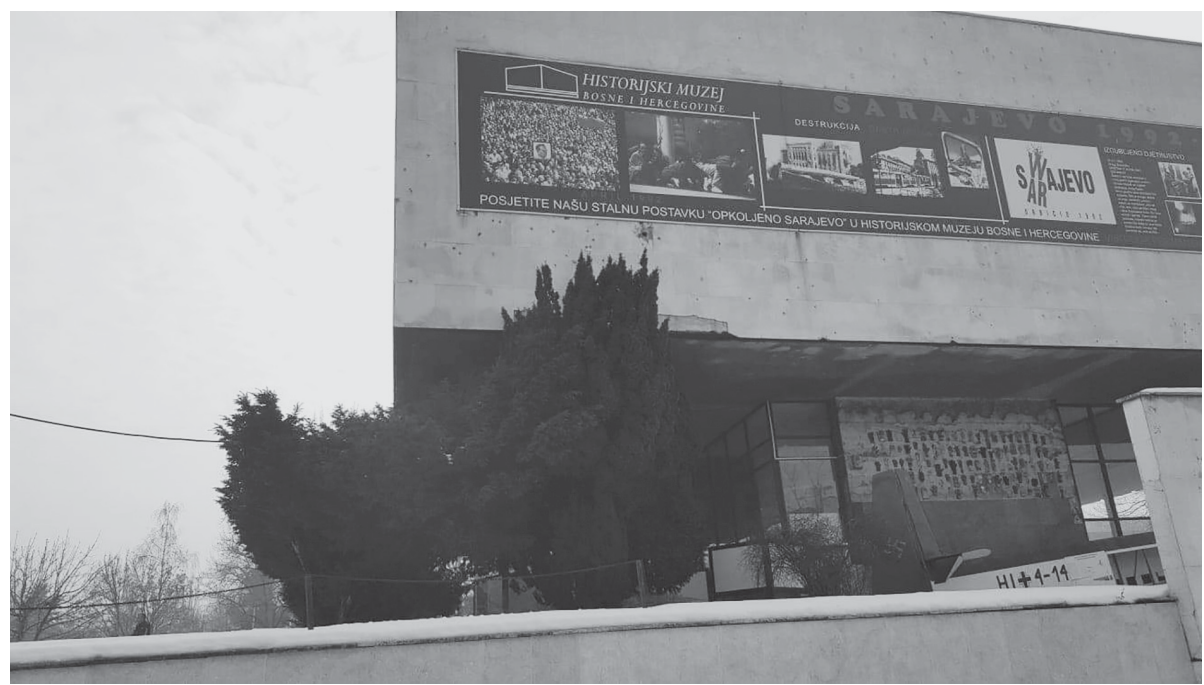

Image 3: History Museum of Bosnia and Herzegovina, detail. Source: Vjeran Pavlaković.

for survival, testifying to the impressive creativity, spirit of resistance, and humour of the town's inhabitants.

Curators started collecting objects from relevant institutions already in 2002, while a public call was issued encouraging Sarajevans to donate objects from/related to the war for the purpose of display at the exhibition. ${ }^{26}$ The collected objects tell a story in which the main actors are the town itself and its citizens who 'despite the conditions they lived in and to which they were exposed, managed to gather strength, creativity, willingness, and the persistence to survive, to organize some kind of a normal life during the war. ${ }^{27}$ Thus, it could be said that the Sarajevans are presented as heroes, though not as the military heroes of the national museums and exhibitions of the former Yugoslavia depicting the national liberation struggle during the Second World War. Now, everyday 'silent' heroes are in focus, ordinary people who managed to survive. To be sure, this is a story of victimization, too, but one in which there are only victims and no perpetrators. The exhibition refuses to blame any side and uses very neutral terms in describing what went on in Sarajevo during the 44-month-long siege. As the museum director explains,

\footnotetext{
${ }^{26}$ Interview with Elma Hašimbegović, director of the History Museum of BiH, Sarajevo, 19 November 2015.

${ }^{27}$ Interview with Elma Hašimbegović, director of the History Museum of BiH, Sarajevo, 19 November 2015.
} 
'the exhibition was set up on the basis of old exhibitions and narratives of the Second World War: the fight of good against evil. There is no mention of perpetrators, only of innocent people, although not even the enemy is mentioned in the sense of a "hateful enemy", but more in the sense that people "got killed". Not people were killed, but people got killed. Very neutral terms were chosen. ${ }^{28}$

The choice of language used at the exhibition is very much 'this happened to us' rather than 'they did this to us'. For example, in the exhibition catalogue, the start of the war in Sarajevo is described as follows: 'on 5 April 1992, the first shots were fired at citizens-participants in a peace rally outside the $\mathrm{BiH}$ Assembly'. No mention is made of who fired the shots. The text continues in the same vein, applying phrases such as 'the city was shelled'. ${ }^{29}$ The authors of the exhibition catalogue explain that 'in this exhibition, we have tried to avoid presenting final judgments, ideological options, and qualifications. We are leaving those to historiography, and time'. ${ }^{30}$

Such an understanding of the role of this exhibition reflects the belief of the museum staff that the task of a museum as an institution is not to be a 'historical guardian of truth', but a place where different historical narratives can be presented, discussed, and contested. Two public events organized in the museum serve as good examples of how the History Museum has interacted with processes of social and political change. The first was the Open Door Week organized in 2012 and triggered by 'The Crisis of the Seven Institutions of National Importance'. One of the main objectives of this initiative was to create a space for dialogue. The museum hosted a public discussion titled 'The History Museum of Bosnia and Herzegovina in modern BosnianHerzegovinian society. In what ways can the Museum contribute to society, and how can society contribute to the work of the Museum?'31

The second example of the museum management's engagement with the local public was its attempt to rethink the 'Besieged Sarajevo' exhibition twenty-five years after the start of the war. In June 2017, the museum staff organized an international workshop with the aim of redesigning the exhibition with the help of both international experts and its local audience. ${ }^{32}$ As the workshop announcement stated,

\footnotetext{
${ }^{28}$ Interview with Elma Hašimbegović, director of the History Museum of BiH, Sarajevo, 19 November 2015.

${ }_{29}^{29}$ Opkoljeno Sarajevo, exhibition catalogue, Sarajevo 2003, 6.

${ }^{30}$ Opkoljeno Sarajevo, 21.

${ }^{31}$ For a detailed discussion of this public debate, cf. Sadiković, Bosnian-Herzegovinian Culture between Erasure and Ethnopolitics.

${ }^{32}$ For a detailed report on the workshop cf. the Memory Lab website, 'Wake Up Europe, Sarajevo Calling.' Connecting Local History and International Perspectives, Workshop Report, Part 1, Sarajevo 2017, http://www.memorylab-europe.eu/files/2018-02/report-memorylabworskhop-historicalmuseum-june-2017.pdf.
} 
'having in mind the new sociopolitical context and the time-distance to the war, it is important to discuss the aims of the exhibition and how it can contribute better to a constructive dialogue about the war and the siege. At the same time, the museum team is convinced that the experiences of the siege of Sarajevo have, beyond Sarajevo and Bosnia and Herzegovina, a European and a universal importance, and intend to emphasize more these international dimensions and entanglements of the exhibition. ${ }^{33}$

In this way, the museum clearly demonstrated that it was not a closed space of institutionalized memory, but a space to be used for dialogue, discussion, and learning. The workshop was, however, only one step in the larger process of rethinking the exhibition. Its title, 'Wake Up Europe, Sarajevo Calling', refers to a postcard created during the siege by the Sarajevan design group TRIO. The postcard was a call for solidarity with the besieged city, aimed at the European public. The title of the workshop also reflects the attempt to go beyond the local, and national, framework of remembering and thinking about the siege of Sarajevo, in addressing core questions of how its history and memories can be embedded in the wider European and global context. The participants of the workshop included a variety of both national and international (European) experts who jointly worked not only on rethinking the current exhibition, but also on questions pertaining to more general issues of bringing together local and international perspectives in exhibitions on sensitive historical topics.

As stated in the exhibition catalogue, the 'Besieged Sarajevo' exhibition

'is a living museum. Although arranged by the museum's curators, it is the work of all Sarajevans. It does not need a guide. All exhibits, all documents, objects, photographs, all sound and visual records, better than any other professional or political explanations, are familiar to and understood by Sarajevans. ${ }^{\prime 34}$

As Joachim von Puttkamer argues, 'to citizens of Sarajevo, the museum has become a place where they can deposit their memories in a dignified manner and where they can reassert their defiance against the destruction of the multi-ethnic modernity for which Sarajevo once stood'. ${ }^{35}$ However, the exhibition is also intended for non-Sarajevans as it seeks to transmit a universal message about human resilience and the 'art of survival' in times of war, while keeping a distance from politicized narratives and leaving space for visitors to form their own opinions. This is why any political context, ideological qualification, or moral judgment has been avoided.

\footnotetext{
${ }^{33}$ Memory Lab, ‘Wake Up Europe, Sarajevo Calling', 2.

${ }^{34}$ Opkoljeno Sarajevo, 21.

${ }^{35}$ Joachim von Puttkamer, No Future? Narrating the Past in Bosnian History Museums, Nationalities Papers 44, no. 5 (2016), 789-803, 794, DOI: 10.1080/00905992.2016.1181052.
} 
Generally, the culture of history related to the recent war in Bosnia and Herzegovina is dominated by different ethnonational narratives that are mutually exclusive, so that it is difficult to maintain a dialogue in a way that is not divisive and antagonistic. In such a context, the History Museum of Bosnia and Herzegovina is an example of an open space where such dialogue is possible, while at the same time reflecting all the difficulties of becoming and remaining such an open space. The situation in which the museum has found itself has, on the one hand, left its management with the freedom to develop its programme and activities without political interference, while on the other, a severe financial crisis is perpetuated necessitating a constant struggle on the part of the management to keep the museum open and to maintain it as an open space. The conceptual approach of the History Museum of Bosnia and Herzegovina makes it specific when compared to other exhibitions in Sarajevo that deal with the recent war and siege, in that it comprehensively addresses the siege in its entirety and complexity. As I will show in the following, other exhibitions focus instead on selected aspects of the topic.

\section{The Tunnel Museum. Institutionalization of a Private Initiative}

One of the museums to present such a slice of the siege of Sarajevo is the Tunnel Museum, initially privately owned. The museum and a small exhibition were first opened in a family house hiding an entrance to the tunnel dug in 1993, during the war. The tunnel linked two Sarajevo neighbourhoods, Dobrinja and Butmir, and was excavated under the runway of Sarajevo Airport. As the museum leaflet states, the tunnel meant rescue and hope for Sarajevo inhabitants and contributed to saving the lives of 'hundreds of thousands of the besieged inhabitants of Sarajevo'-thus it was 'given its fully deserved name, the Tunnel of Hope'. ${ }^{36}$ Before the town's authorities recognized the meaning and value of preserving the remnants of the tunnel, it was maintained thanks to the will and interest of individuals. The family owning the house opened what was left of the tunnel (some $20 \mathrm{~m}$ ) to visitors, mainly foreigners, almost immediately after the end of the war, in 1997. However, neither the local (cantonal) authorities nor the federal government were particularly concerned or interested in what was going to happen with the remnants of the 'Tunnel of Hope'-after all, one of the most important sites of memory of the war in Sarajevo. ${ }^{37}$ Talks on expanding the private Tunnel Museum into a memorial museum of the siege began in 2003, but the city authorities were

\footnotetext{
${ }^{36}$ Memorial Fund, Tunnel of Hope. Rescue in War, Memory in Peace (Tunnel Museum leaflet in possession of the author).

${ }^{37}$ I. Trepalovac, Spas u danima rata, uspomena u miru, Oslobođenje, 31 July 2004, 12.
} 


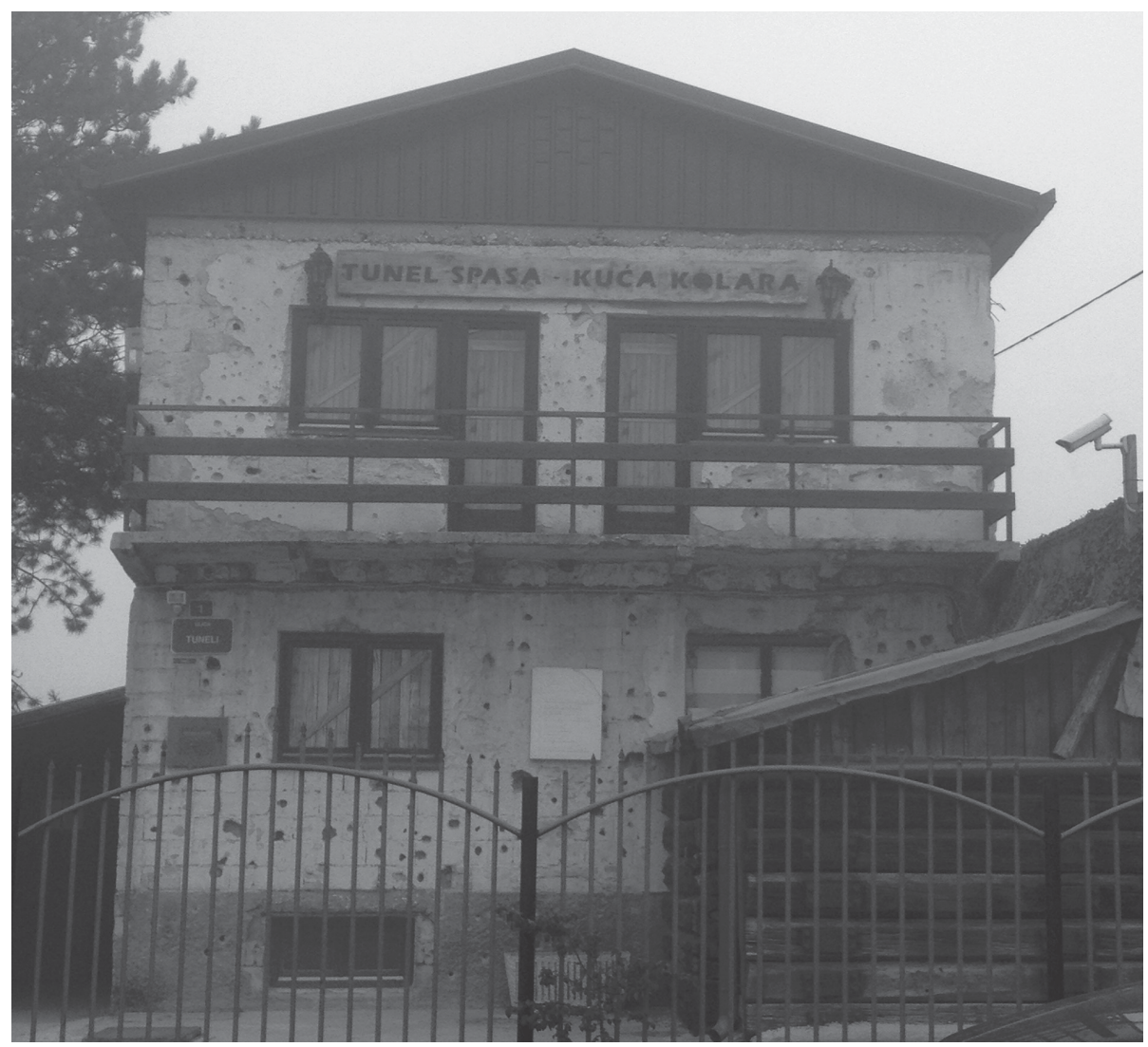

Image 4 : The Tunnel Museum. Source: Tamara Banjeglav.

hesitant to take over the site. ${ }^{38}$ In 2008, the Sarajevo Canton department for the protection of monuments in the canton came up with a proposal for a memorial museum dedicated to the siege of Sarajevo, which was to be opened on the Tunnel Museum premises, integrating the existing museum. However, since local authorities did not secure any funding, such a museum was never opened..$^{39}$

In the early years of discussion on its destiny, the Tunnel Museum was supposed to become a branch of the City of Sarajevo Museum. However, given that the entrance to the tunnel in Butmir, i.e. the area near Sarajevo Airport,

\footnotetext{
${ }^{38}$ Zaboravljeni tunel, Nezavisne novine, 6 November 2005, 12-13; Nermina Voloder, Uskoro rekonstrukcija 'tunela spasa', Nezavisne novine, 14 June 2008, 26.

${ }^{39}$ Zaboravljeni tunel, 12-13.
} 


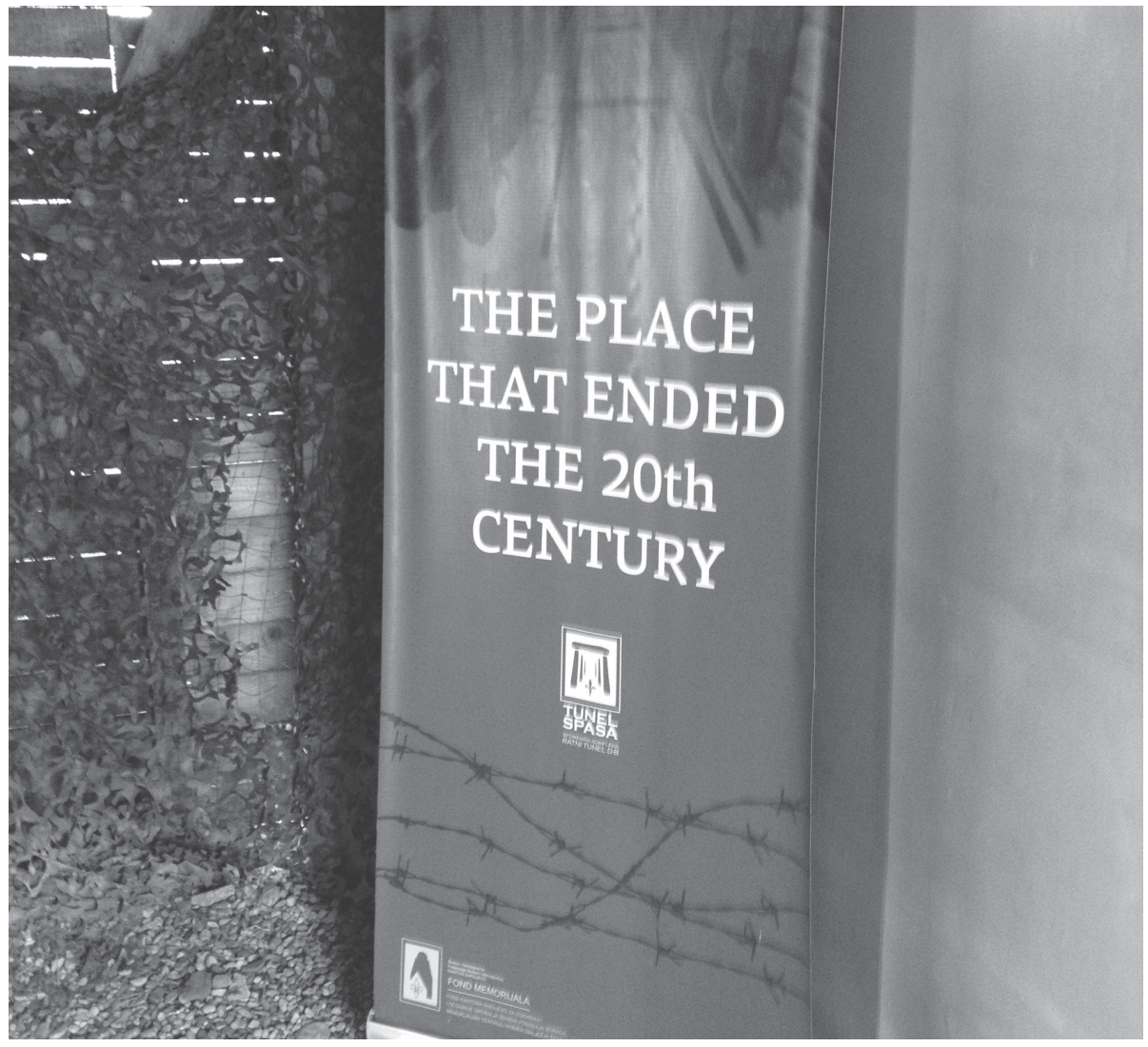

Image 5: The Tunnel Museum, detail. Source: Tamara Banjeglav.

was not actually a part of the City of Sarajevo, the obstacle was that it was not located within the City Museum's jurisdiction. Instead, in 2012, the government of Sarajevo Canton, more precisely the Ministry for War Veterans and the Ministry of Finance, assumed the ownership of the museum and allocated its administration to the 'Sarajevo Canton Fund for the Protection and Maintenance of Cemeteries of Šehids and Fallen Soldiers, Memorial Centres and Memorials to Victims of Genocide' ${ }^{40}$ Thus, since the Tunnel Museum turned out not eligible as a branch of the City Museum, it became a memorial complex managed by a fund that primarily takes care of the cemeteries of fallen BiH Army soldiers.

${ }^{40}$ Interview with Dina Memić, curator at the Tunnel Museum, Sarajevo, 13 November 2015. 
These administrative issues notwithstanding, the narrative presented in the museum's permanent exhibition is a very private one. It mainly reflects the personal experiences of the owner of the house as well as the testimonies of people who participated in digging the tunnel and who used it during the war. The timeline starts with the beginning of the siege, tells the story of the hardships of survival and the process of digging, and finally presents the tunnel's crucial role for the very survival of the city. Throughout, visitors are encouraged to assume admiration for those who suffered but survived owing to their spirit of resistance and strength. Foreign tourists in particular have recognized the Tunnel Museum as unique and as one of the most interesting memorial sites related to the siege of Sarajevo. In fact, in 2015, 80 to $85 \%$ of visitors to the museum were tourists from abroad. ${ }^{41}$ For this reason, the exhibition is designed in a way to help tourists understand why it was necessary to build the passage. It includes a documentary film showing life during the siege, and footage of the excavation work. However, scenes of massacres and dying are not presented here. ${ }^{42}$ The museum features a 'survival room' exhibiting items that were needed for everyday survival during the siege, quite similar to the exhibits collected in the History Museum. Objects in this room include a handmade stove, an oil lamp, and a lantern, all of which remind visitors of the fact that there was no gas or electricity. This room was added to the main exhibition in later years, in 2016, and is located outside the main museum building, indicating that this museum and its exhibition are less about the war and siege, although these topics are necessarily interrelated, than about the uniqueness of the tunnel symbolizing survival in impossible conditions.

The Tunnel Museum is an example of an amateur endeavour to set up a museum exhibition and arrange artefacts, as is seen in the architecture of the museum building itself. As Lejla Kreševljaković observes, 'from access to the facility, to the way in which the exhibits are presented, an amateur approach to the creation of this museum is obvious', resulting from the fact that the representatives of the Memorial Fund are no experts in the field of museology. ${ }^{43}$ Also, this museum does not maintain strong relationships with the local public, compared to the History Museum of $\mathrm{BiH}$, in terms of organizing public debates, discussions, and educational activities. It has remained mostly oriented towards foreign visitors and tourists on their 'dark tourism' ventures into the city. In contrast to the other museums discussed in this article, the Tunnel Museum is provided with government support, though this support

${ }^{41}$ Interview with Dina Memić, curator at the Tunnel Museum, Sarajevo, 13 November 2015.

${ }^{42}$ Author's observation, June 2017.

${ }^{43}$ Lejla Kreševljaković, Sarajevo Museums Representing the Post-War B\&H Society in Transition, in: Amir Pašić / Borut Juvanec/Jose Luis Moro, eds, The Importance of Place. Values and Building Practices in the Historic Urban Landscape, Cambridge 2016, 119-132, 125. 
arrived with considerable delay. It took Sarajevo Canton as many as fifteen years after the museum first opened to assume its administration.

\section{The War Childhood Museum. A Private Initiative without Institutional Support}

One of the more recent additions to the map of Sarajevo's war-related museums is the War Childhood Museum, a project-based endeavour initiated by Jasminko Halilović, himself a child during the war. Halilović first published his book War Childhood. Sarajevo 1992-1995 that contains over 1,000 memories from people who were children or adolescents during the war and are now scattered all around the world. ${ }^{44}$ The book foregrounds personal testimonies of growing up in wartime.

The War Childhood Museum represents the next step in Halilović's 'Childhood in War' project and was opened in January 2017.45 This museum, just like the Tunnel Museum, exhibits a selected sphere of life under the siege, focusing on the specificities of children's experiences. The idea, however, is not new, since the fate of children is already well represented in the History Museum's 'Besieged Sarajevo' exhibition. The War Childhood Museum's particular goal in documenting experiences of growing up during the war is to include a celebration of the ways in which children survived and resisted. ${ }^{46}$ The museum's collection contains personal belongings, video testimonies, photographs, letters, diaries and other documents offering valuable insight into the unique experience of growing up in wartime. ${ }^{47}$ In addition to exhibiting personal belongings of children who survived the war, the museum stores personal recollections collected through oral history methodology, i.e. audio and video materials of individuals who were children and adolescents during the war. While the personal stories collected for the book were told by people who spent their childhood in Sarajevo, the museum has collected testimonials from individuals from all over Bosnia and Herzegovina, 'in order to give the audience an opportunity to hear alternative narratives and to avoid manipulation of collective memories'. ${ }^{48}$ According to the museum's director, Jasminko Halilović, 'this is a museum that brings people closer together and opens up a dialogue, and it might be because of this that it has been continuously

\footnotetext{
${ }^{44}$ Jasminko Halilović, Djetinjstvo u ratu. Sarajevo 1992.-1995., Sarajevo 2012.

${ }^{45}$ Cf. the War Childhood project website, https://warchildhood.org/museum/.

${ }^{46}$ Interview with Selma Tanović, War Childhood Museum project team member, Sarajevo, 4 November 2015.

${ }^{47}$ Cf. the War Childhood project website, https://warchildhood.org/museum/personalbelongings/.

${ }^{48}$ Interview with Selma Tanović, War Childhood Museum project team member, Sarajevo, 4 November 2015.
} 


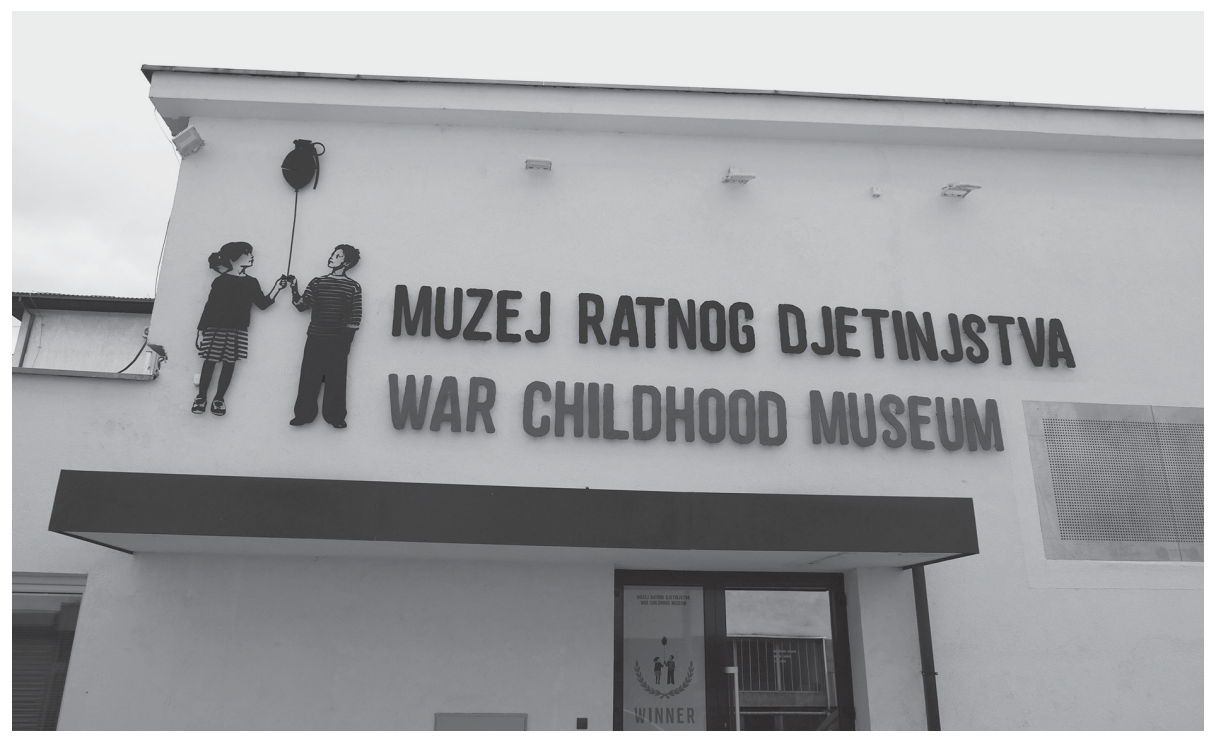

Image 6: Entrance to the War Childhood Museum. Source: Judith Brandt.

obstructed' ${ }^{49}$ The obstruction mentioned here refers to the difficulties faced by the museum management when attempting to ensure a space for the collection. The local government only allocated such a space after the issue had been raised in the media. ${ }^{50}$ In an open letter, the museum's director accused the minister of culture of the Federation of Bosnia and Herzegovina of preventing the opening of the museum, after the ministry decided not to grant the museum financial support. In the letter, Halilović stated the reason for such a refusal. In his view, it lay in the fact that the museum promoted unity among BiH's constituent nations. This, he argued, did not suit the ethnonational outlook promoted by all political parties in $\mathrm{BiH}^{51}$

However, the museum is now located in the old part of the city centre, which makes it an attractive tourist destination. It pursues an active social media

${ }^{49}$ Priča sa sretnim krajem. U Sarajevu svečano otvoren muzej ratnog djetinjstva, Klix, 28 January 2017, https://www.klix.ba/magazin/kultura/prica-sa-sretnim-krajem-u-sarajevusvecano-otvoren-muzej-ratnog-djetinjstva/170128089.

${ }^{50}$ Vedrana Maglalija, Zašto Sarajevo nema prostora za Muzej ratnog djetinjstva?, Al Jazeera Balkans, 26 July 2016, http://balkans.aljazeera.net/vijesti/zasto-sarajevo-nema-prostora-zamuzej-ratnog-djetinjstva.

${ }^{51}$ Otvoreno pismo Jasminka Halilovića. Ministrice, zašto ste pokušali spriječiti otvaranje Muzeja ratnog djetinjstva?, Klix, 16 December 2016, https://www.klix.ba/magazin/kultura/ otvoreno-pismo-jasminka-halilovica-ministrice-zasto-ste-pokusali-sprijeciti-otvaranjemuzeja-ratnog-djetinjstva/161216093. 
strategy and is present on smartphone apps, thus comprehensively displaying a well thought-out marketing strategy and a commercial imperative. For example, the price of a museum ticket for adults is double that of a ticket for the History Museum, reflecting the management's intention for the museum to be self-sustainable 'in order to avoid any political pressure and manipulation'. ${ }^{52}$ In working towards this goal, the museum also hosts an online store in which various objects and souvenirs relating to the museum can be bought. An interesting item on offer is a lifetime museum pass, the price of which increases depending on whether you want to be a 'friend', 'partner', or 'sponsor' of the museum. With its developed business strategy and the fact that it is not supported financially by any level of the government, this museum stands out from the other museums in the city that still depend on, or at least hope for, some kind of institutional support.

\section{Memorializing the Siege, or Seizing an Opportunity?}

Today, the public memory of the war in Sarajevo is strongly linked to personal experiences and is constructed in accordance with the interests of those with the power and ability to create part of public memory, such as associations of war veterans, civil society organizations, and even individuals. Besides the three analysed museums, there are other museums and memorial initiatives in Sarajevo that were either planned or have been opened and relate, at least partly, to the siege.

One of these is the 'Sarajevo Siege Museum', officially announced in 2011 and which was supposed to open the following year, on the twentieth anniversary of the start of the war. ${ }^{53}$ 'The core of the planned museum was the FAMA Collection of oral histories and artistic responses to the experience of war in Sarajevo, which were generated during the early 1990s and have been continually added to since then.' ${ }^{54}$ In 1990, FAMA was founded as one of the first independent media organizations in Bosnia and Herzegovina. Today, its collection is still only available online, as a virtual museum, and most of the installations for the proposed physical museum-subsumed under the title 'The Art of Living'-are designed as multimedia presentations and are thus similar to what can be found online. ${ }^{55}$

\footnotetext{
${ }^{52}$ Interview with Selma Tanović, War Childhood Museum project team member, Sarajevo, 4 November 2015.

${ }_{53}$ A. Mešić, Predstavljen projekat Muzeja opsade Sarajeva. Dostignuća građana iz ratnih dana, Oslobođenje, 31 May 2011, 23.

${ }^{54}$ Gunzburger Makaš, Museums and the History and Identity of Sarajevo.

55 Gunzburger Makaš, Museums and the History and Identity of Sarajevo. Cf. the FAMA Collection website, http://www.famacollection.org/.
} 
The museum was meant to 'create a new way of learning about the phenomenon of the siege of Sarajevo by mapping facts, causes and consequences, as well as ways of survival in a besieged city'. ${ }^{56}$ Similarly to the 'Besieged Sarajevo' exhibition in the History Museum, the focus is on the everyday life and experience of living under siege, rather than on military actions or political context. The museum project strove to provide facts and information through interactive maps, digital chronology, an animated encyclopaedia, films, videos, photographs, and sketches. ${ }^{57}$ The architects of the museum building wanted to 'communicate' the experience of the siege to visitors, which is why their solution for the planned museum building saw visitors enter in the same ways in which it had been possible to enter Sarajevo during the war-either through a replica of the tunnel or by 'landing' on the roof..$^{58}$ It was envisaged that the museum would open in a purpose-built building in the centre of the city, at a location donated by the City Centre Municipal Authority. The latter did allocate some funds for the start of construction work. However, these proved insufficient, so that the founders of the consortium of four organizations that initiated the museum project-apart from FAMA, these were the MESS Theatre Festival, the Youth Initiative for Human Rights, and the association 'Education Builds Bosnia and Herzegovina'-started collecting donations. The museum, thus, was a project-based idea initiated by four civil society organizations that decided to raise money through fund-raising campaigns and planned a self-sustainable model for the museum once it opened. However, the museum has not been built to date, and what is more, in late 2017 the initiators announced that they had given up on pursuing their idea..$^{59}$

Another project with a similar aim of founding a 'Museum of the Siege and Defence of Sarajevo 1992-1995' was initiated in 2007 by the war veterans' association Zelene beretke ('Green Berets'). This museum was due to open in April 2008, on the anniversary of the start of aggression against the capital of $\mathrm{BiH}$. The City Centre Municipal Authority allocated a space for the museum to the association, while Sarajevo Canton ministries as well as numerous war veterans' associations secured funds. The plan was to exhibit weapons, uniforms, and documents relating to the defence of the town and the army units that defended it. However, apart from dealing with the military, the museum was to offer insight into the civilian aspects of the siege. In this sense, the

\footnotetext{
${ }^{56}$ M. Du, Spomenik ljudskom umu tokom opsade, Dani, 3 June 2011, 68.

${ }^{57} \mathrm{Du}$, Spomenik ljudskom umu tokom opsade, 68.

${ }^{58}$ The Siege of Sarajevo Museum. The Art of Living 1992.-1996. Architectural Conceptual Design, FAMA Collection, no date, 3, http://www.famacollection.org/museum_presentation. pdf.

${ }^{59}$ Kako je politika blokirala projekt Muzeja opsade Sarajeva, tvorci ideje se žale na opstrukcije, Klix, 3 October 2017, https://www.klix.ba/vijesti/bih/kako-je-politika-blokiralaprojekt-muzeja-opsade-sarajeva-tvorci-ideje-se-zale-na-opstrukcije/171002134.
} 
exhibition would partially overlap with the exhibits in the History Museum, but also with the 'survival room' in the Tunnel Museum, as it, too, would display objects that citizens made themselves during the war in order to survive. According to media announcements, the planned museum was to feature a projection room, a seminar room and a 'šehid room', intended to contain digital photographs and biographies of fallen šehids. ${ }^{60}$ While this term originally referred to Muslims who died a heroic death fighting for their faith, as martyrs, over time the term has become more comprehensive, so that today it encompasses all categories of civil society. ${ }^{61}$ Thus, the museum would not only testify to the heroic defence of the town, but would also be a memorial to all fallen soldiers and šehids.

In this regard, the museum's focus would overlap with another memorial, namely the Kovači Cemetery, one of the oldest Sarajevan Muslim graveyards dating back to the $15^{\text {th }}$ century. The cemetery was re-activated during the siege and turned into a memorial complex in 1997. Like the Tunnel Museum, the Kovači Cemetery is managed by the 'Sarajevo Canton Fund for the Protection and Maintenance of Cemeteries of Šehids and Fallen Soldiers, Memorial Centres and Memorials to Victims of Genocide'. This large memorial complex includes a section where fallen soldiers of the Army of $\mathrm{BiH}$ are buried, together with their chief commander, Alija Izetbegović. Nearby is the Museum of Alija Izetbegović, dedicated to the first president of the presidency of the newly independent Republic of Bosnia and Herzegovina in 1992. As Amra Čusto argues, owing to the fact that no central monument dedicated to the siege of the city has yet been erected in Sarajevo, and since the highest number of fallen fighters and šehids are buried at Kovači Cemetery, it is perceived by the public as the most important site of memory related to the war. ${ }^{62}$ In fact, the plan to locate the Museum of Siege and Defence of Sarajevo 1992-1995 in the vicinity of the Kovači memorial complex raises the question of the necessity of another museum that would exhibit and memorialize what has already been exhibited and memorialized in the city in various locations and museums. And although its imminent opening was announced in July 2015, the event has not yet taken place. ${ }^{63}$

\footnotetext{
${ }^{60}$ A. Halebić, Svjedočenje o herojskoj obrani grada, Oslobođenje, 14 September 2007, 16.

${ }^{61}$ On the expanded semantics of šehid cf. Amra Čusto, Uloga spomenika u Sarajevu u izgradnji kolektivnog sjećanja na period 1941.-1945. i 1992.-1995. Komparativna analiza, Sarajevo 2013, 87.

${ }_{62}$ Čusto, Uloga spomenika u Sarajevu u izgradnji kolektivnog sjećanja, 91.

${ }^{63}$ Fišo. Uskoro završetak radova u Muzeju opsade i odbrane Sarajeva 1992.-1995., Klix, 21 July 2015, https://www.klix.ba/magazin/kultura/fiso-uskoro-zavrsetak-radova-u-muzejuopsade-i-odbrane-sarajeva-1992-1995/150721075.
} 
A museum that stands out from the others discussed in this article through the manner in which it, very vividly, presents violence committed during the war in $\mathrm{BiH}$, is the Museum of Crimes against Humanity and Genocide. Although the museum does not exclusively focus on the siege of Sarajevo, it is discussed here since it does exhibit materials relating to the blockade, such as a documentary video and objects used during the siege. The museum was opened in July 2016 as the result of a private initiative by several members of the Association of Camp Inmates of Bosnia and Herzegovina. Although privately owned, Sarajevo Canton granted the museum space in the very centre of the city. As the museum leaflet explains, the museum 'authentically, symbolically and illustratively shows the extent of committed crimes as well as the character of the war in Bosnia and Herzegovina'. ${ }^{64}$ Some of the documents, objects and video materials exhibited in the museum were obtained with the help of the International Criminal Tribunal for the Former Yugoslavia (ICTY) ${ }^{65}$ The exhibition '20 Years of the International Criminal Tribunal for the Former Yugoslavia', which was first put on display in the History Museum of Bosnia and Herzegovina between 2013 and 2016, was later moved to the Museum of Crimes against Humanity and Genocide.

As opposed to the display in the History Museum, the permanent exhibition in this museum strongly insists on the clear and visual depiction of horrifying crimes, using some very explicit photographs of violence and mutilated bodies. While, as described above, the museum professionals at the History Museum have mostly avoided scenes of violence in their 'Besieged Sarajevo' exhibition, the former camp inmates who established this exhibition have clearly intended to shock visitors. Here, the visual representations of violence are often accompanied by the victims' personal belongings. One room also contains a replica of a prison cell.

Like the Tunnel Museum, this museum is visited mostly by tourists and guests to Sarajevo, who can hardly miss it given its central location. Yet, the museum is not only part of the city's range of 'dark tourism' sites, but also offers important information about the war in $\mathrm{BiH}$. Although the museum is a private enterprise and was not initiated by the ICTY, it plays ICTY outreach video materials that include testimonies, excerpts from trials, and documentaries about the war. Thus, this museum is more than a regular tourist venue for visitors interested in BiH's recent history. It also plays an important role for researchers looking for information on the criminal justice proceedings in $\mathrm{BiH}$ and about the crimes and mass violence committed during the war. In

\footnotetext{
${ }^{64}$ Museum of Crimes Against Humanity and Genocide 1992-1995, leaflet, Sarajevo 2016.

${ }^{65}$ U Sarajevu otvoren muzej zločina protiv čovječnosti i genocida 1992-1995, Dnevni Avaz, 19 July 2016, https://avaz.ba/vijesti/246827/u-sarajevu-otvoren-muzej-zlocina-protivcovjecnosti-i-genocida-1992-1995-foto.
} 
this way, the museum importantly complements the other exhibitions on the siege of Sarajevo as it offers visitors additional information not just about the siege, but about the war in $\mathrm{BiH}$ in general.

The flourishing of private museum initiatives after a war or period of political violence and repression is not new or specific to the case of postwar Sarajevo. With regard to Eastern Europe after communism, Sarajevo's various initiatives and actually established museums present an interesting comparative case. After 1989, some countries decided to capitalize on their socialist past in the process of developing tourism, resulting in a number of private commemorative initiatives across Eastern Europe. For example, more than two dozen private museums representing everyday life under socialism exist today in East Germany. Jonathan Bach notes that 'most of these are amateur operations in the strict sense, with staff whose knowledge or personal experience of the GDR-rather than curatorial or museum backgrounds-legitimize their roles'. ${ }^{66}$ Historians may critically dismiss such initiatives as amateurish. I would concur with Bach, however, who argues that as a social phenomenon such private museums are a substantial part of the process of working through the past. If, in Germany, such museums 'play a role in making the GDR everyday available for contemporary representation', the same is certainly valid in the more complex context of Sarajevo. ${ }^{67}$

\section{Conclusion}

In Bosnia and Herzegovina, national museums do not have the status they enjoyed in socialist Yugoslavia when they had the clear task of articulating the dominant ideology of 'brotherhood and unity' and played an important role in educating the young about the national liberation struggle and its legacy in contemporary society. In post-Dayton $\mathrm{BiH}$, museums instead have been left with uncertain legal status, and the state does not guarantee the financial stability needed for the survival of these institutions.

Consequently, the museums and initiatives discussed in this article have evolved bottom-up rather than top-down, which I would see as much as an opportunity as a complex of problems. As the case of the History Museum of Bosnia and Herzegovina has shown, the political deadlock in the country that has perpetuated paralysis in terms of the museum's operation has at the same time allowed it to open up a narrative about the recent past through becoming an open space and engaging in dialogue with the local public. Public discussions such as those organized in the History Museum challenge the dominant,

\footnotetext{
${ }^{66}$ Jonathan Bach, Collecting Communism. Private Museums of Everyday Life under Socialism in Former East Germany, German Politics and Society 33, no. 1-2 (2015), 135-145.

${ }^{67}$ Bach, Collecting Communism, 142.
} 
nationalized narratives and offer alternative interpretations of BiH's recent history. Thus, the lack of a shared history in BiH presents an opportunity for 'memory entrepreneurs' to create a space for communication where memory competition can be transformed into a constructive dialogue about the past. As Nicolas Moll observes, 'the main challenge is not the creation of a common Bosnian memory identity but the creation of a shared Bosnian memory space, where the different memory entrepreneurs and narratives would enter into critical and self-critical communication with each other' ${ }^{68}$

Maintained with much improvisation, the museums analysed in this article reflect an amateur approach to musealization that sets them apart from state-sponsored museums elsewhere in Central and Southeastern Europe, where memories have become more institutionalized and officialized over the last thirty years. The examples of the musealization of Sarajevo's recent past may be driven not least by commercial and economic motivations rather than solely by the urge to attempt to come to terms with the traumatic past. And yet, the museums provide valuable venues for addressing this past and can contribute to an enhanced understanding of the experiences of Sarajevans living under siege and of their struggle for survival. Seen as a social phenomenon, these museums contribute to 'living history', while a more static (and statist) representation of 'how it really was' has hardly been initiated beyond the trodden nationalist paths. As such, the museums analysed here have the potential to become and remain critical spaces where history, memory, and identity can be examined, contested, and negotiated.

\section{CORRESPONDING AUTHOR}

Tamara Banjeglav Sveučilišna avenija 4, 51000 Rijeka, Croatia. E-mail: banjeglavt@gmail.com

${ }^{68}$ Moll, Fragmented Memories in a Fragmented Country, 22. 